Document downloaded from:

http://hdl.handle.net/10251/57334

This paper must be cited as:

Sanchez, F.; MJ Rodríguez-Älvarez (1999). Effect of pH, temperature ,conductivity and sediment size on thorium activities along Jucar River (Spain). Journal of Radioanalytical and Nuclear Chemistry. 242(3):671-681. doi:10.1007/BF02347378.

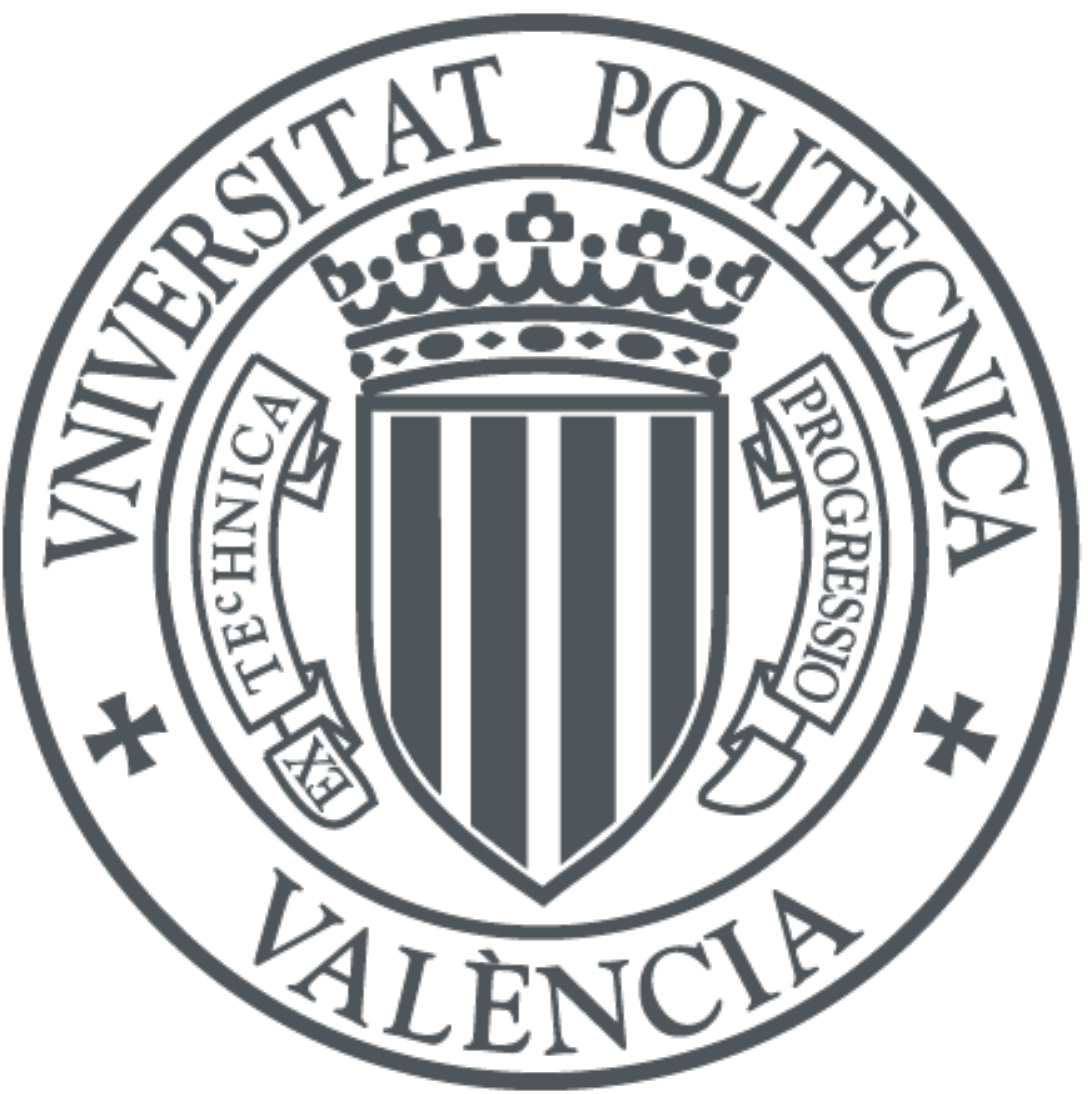

The final publication is available at

http://dx.doi.org/10.1007/BF02347378

Copyright Springer Verlag; Akadémiai Kiadó

Additional Information 


\title{
Effect of pH, temperature, conductivity and sediment size on thorium and radium activities along Jucar River (Spain)
}

\author{
F. Sanchez, ${ }^{1}$ M. J. Rodriguez-Alvarez ${ }^{2}$ \\ IInstituto de Fisica Corpuscular, Avda. Dr. Moliner 50, Burjasot 46100 Valencia, Spain \\ ${ }^{2}$ Dpto. Matemática Aplicada, Univ. Politécnica de Valencia, Camino de Vera sin, 46020-Valencia, Spain
}

(Received June 1, 1999)

\begin{abstract}
A study is presented on the distribution of thorium and radium isotopes in sediments, suspended matter and water collected along Jucar river (East of Spain), using low-level $\alpha$-spectrometry. The first aim of this work is to study the thorium and radium activity in water, sediment and suspended matter and their dependence on $\mathrm{pH}$, temperature, conductivity and sediment sizes along Jucar river. The analysis of activity variation with these parameters will provide information about the dynamics of these radionuclides in rivers. The values obtained for the distribution factors between suspended matter and water $\left(K_{d}\right)$ are also discussed.
\end{abstract}

\section{Introduction}

As explained in a previous paper, ${ }^{1}$ Jucar River is one of the main important rivers in Eastern Spain $(\approx 500 \mathrm{~km})$. There are, in principle, no local sources of uranium, thorium and radium affecting the river. ${ }^{2-4}$ Thus, it is assumed that the radioactivity levels of these isotopes will depend mainly on the geological substratum and dynamics of the river.

The Cofrentes Nuclear Power Plant which has a BWR reactor is located beside Jucar River. The Nuclear Plant outlet is placed just in Jucar River, but no uranium, thorium or radium release is expected.

Recently, 3,4 correlations between uranium activity and activity ratios and $\mathrm{pH}$ were found in Jucar river. In this work we study thorium and radium activities in sediments, suspended matter and water along Jucar river in order to investigate if there is a behavior similar to that we found for uranium. A low level $\alpha$-spectrometry procedure was developed ${ }^{5}$ in our laboratory and used for these measurements. We have found a dependence between radium activities in water and $\mathrm{pH}$, but no so correlated as in uranium case. No dependence has been found for thorium samples.

Due to short half-life of ${ }^{224} \mathrm{Ra}$ this isotope is analyzed only in water samples. Consequently ${ }^{226} \mathrm{Ra} / 224 \mathrm{Ra}$ activity ratio is studied only in water samples. ${ }^{228} \mathrm{Th} / 232 \mathrm{Th}$ and ${ }^{230} \mathrm{Th} / 232 \mathrm{Th}$ activity ratios are studied for water, sediments and suspended matter samples. Disequilibrium is found and possible causes are discussed. Different authors have reported a ${ }^{228} \mathrm{Th} / 232 \mathrm{Th}$ and ${ }^{230} \mathrm{Th} /{ }^{232} \mathrm{Th}$ activity ratio disequilibrium for other systems (rivers around the world, ${ }^{6}$ Guadalquivir river, ${ }^{7}$ near Phosphate Fertilizer Processing Industries). ${ }^{8}$ However no correlation has been found with $\mathrm{pH}$, temperature or conductivity for these activity ratios.
The distribution factors $\left(K_{d}\right)$ between water and suspended matter for thorium and radium have been calculated. The main contribution to thorium activity is found to be the geological substratum. Other authors have reported $K_{d}$ dependence from $\mathrm{pH}$, temperature or conductivity in other rivers 9,10 for cesium. Our aim was to investigate if there was any dependence for thorium and radium distribution factors as we did previously for uranium. 5

\section{Experimental}

\section{Sampling}

Samples were collected along Jucar River on January 1996. A total of ten sampling points were considered (Fig. 1). 30 liters of water and $\approx 2 \mathrm{~kg}$ of sediments were collected at each sampling point. In the last point, it was not possible to collect sediment sample because the river is canalized artificially. Three samples have been taken close to the Cofrentes Nuclear Power Plant in order to study a possible influence of the Nuclear Plant on thorium and radium levels. Samples were taken upstream and downstream from the outlet of Cofrentes Nuclear Plant, one at Cabriel river, the main affluent of Jucar river (Cabriel River flows into Jucar River just before the outlet of Cofrentes Nuclear Plant) and finally at its mouth. Conductivity, $\mathrm{pH}$ and temperature were measured in situ (Table 1). Knowledge of these parameters is assumed to be important for understanding the behavior of thorium and radium concentrations, activity ratios and distribution factors.

\footnotetext{
' E-mail: Filomeno@evalvx.ific.uv.es
} 


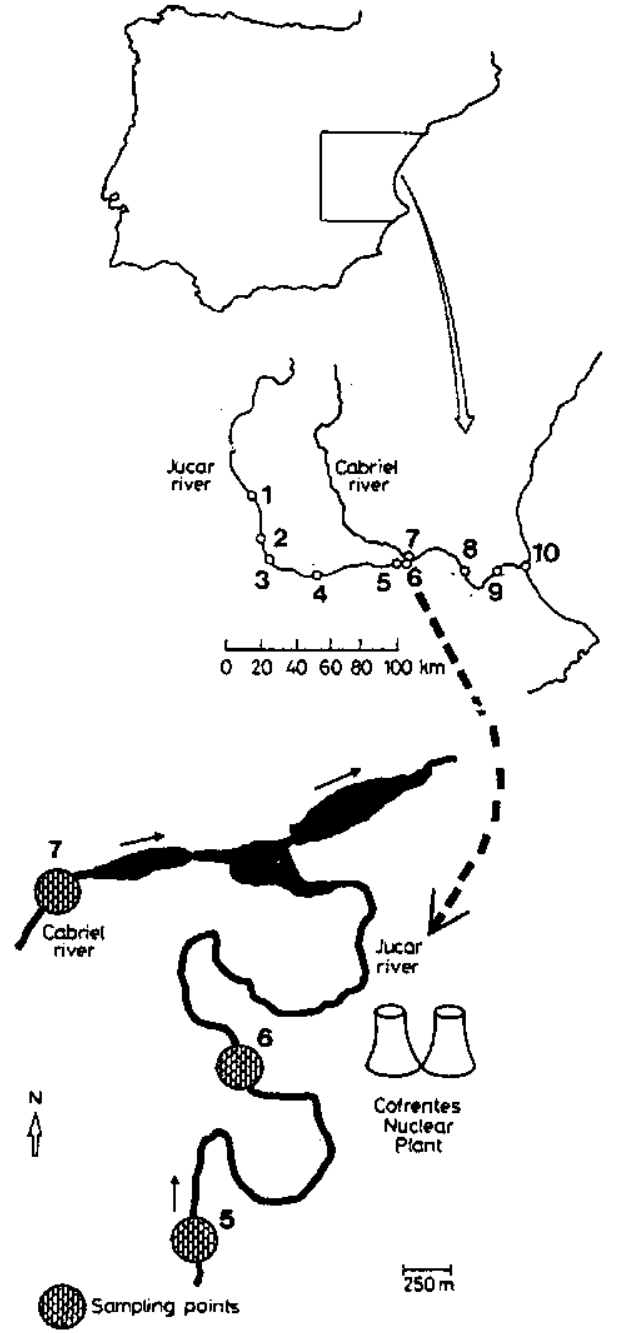

Fig. 1. Sampling points along Jucar and Cabriel rivers

Table I. $\mathrm{pH}$, temperature and conductivity along Jucar river

\begin{tabular}{lccc}
\hline ID. & $\begin{array}{c}\mathrm{pH} \\
\pm 0.01\end{array}$ & $\begin{array}{c}\text { Temperature, } \\
\pm 0.1^{\circ} \mathrm{C}\end{array}$ & $\begin{array}{c}\text { Conductivity, } \\
\pm 1 \mu \mathrm{S} \cdot \mathrm{cm}^{-1}\end{array}$ \\
\hline 1 & 8.84 & 7.5 & 675 \\
2 & 8.84 & 7.1 & 697 \\
3 & 8.34 & 9.0 & 751 \\
4 & 7.70 & 14.2 & 940 \\
5 & 8.60 & 11.5 & 1131 \\
$6 * 2$ & 8.40 & 8.5 & 734 \\
$7 * 1$ & 8.30 & 12.0 & 952 \\
8 & 8.30 & 8.0 & 720 \\
9 & 7.92 & 8.0 & 688 \\
10 & 8.42 & 16.0 & $1572 \cdot 10^{3}$ \\
\hline
\end{tabular}

The sample marked*1 in Table 1 (No. 7) is not from Jucar river, but from Cabriel river, just before it flows into Jucar river, and the sample marked*2 (No. 6) was taken just before the outlet of Cofrentes Nuclear Plant.
Last point sample (No. 10) was taken just into the mouth of the river in the sea, so river water is mixed with sea water and conductivity increases by a factor of $\approx 10^{3}$.

\section{Procedure}

Suspended matter in water samples was separated by filtration $(0.45 \mu \mathrm{m})$ and the water was immediately acidified with $\mathrm{HNO}_{3} .20$ liters of filtered water were used for thorium and radium analysis. Sediments were sieved in four sizes. The following notation has been used: $\quad F 1=0.143-0.6 \mathrm{~cm}$ (fine gravel), $\mathrm{F} 2=0.063-0.143 \mathrm{~cm}$ (coarse sand), F3 $=\leq 0.063 \mathrm{~cm}$ (clay, silt and medium sand) and $\mathrm{FT}=$ sediment without sieve. The amount of each type of sediment analysed separately varies between 1 and $5 \mathrm{~g}$. Table 2 shows percentages of each sized sediment.

The extraction method used in this work is that previously developed in our laboratory 4,5 that's why only a brief description is given here. Solid samples are digested with an acid treatment, and finally dissolved in $500 \mathrm{ml}$ of distilled water and treated as a liquid sample. Samples were preconcentrated by co-precipitation with $\mathrm{KMnO}_{4}$. Thorium/radium separation was done by using TBP (tri-butil-phosphate) and finally purified using ion exchange resins (Bio-Rad AG $1 \times 8$ hydrochloric form for thorium samples and Bio-Rad AG 50WX8, 200-400 mesh for radium samples). Afterwards samples were electrodeposited $^{1-14}$ on a stainless steel planchet of $2.5 \mathrm{~cm}$ diameter. The plated samples are measured by a silicon surface barrier detector. Typical recovery yields of the experimental procedure were $\approx 85 \%$ for water samples and $75 \%$ for sediment and suspended matter samples. The FWHM of the spectra varies between $20 \sim 23 \mathrm{keV}$ for a silicon barrier detector of $19 \mathrm{keV}$ intrinsic resolution.

Sample counting time was about 15 days for thorium water samples being slightly lower for the other samples.

Table 2. Percentages in grain size for sediment samples along Jucar River; F1: grain size $0.6-0.143 \mathrm{~cm} ; \mathrm{F} 2$; grain size $0.143-0.063 \mathrm{~cm}$; F3: grain size $\leq 0.063 \mathrm{~cm}$; FT: all without sieving

\begin{tabular}{cccc}
\hline ID. & $\begin{array}{c}\text { F1, } \\
\%\end{array}$ & $\begin{array}{c}\text { F2, } \\
\%\end{array}$ & $\begin{array}{c}\text { F3, } \\
\%\end{array}$ \\
\hline 1 & 95 & Negligible & Negligible \\
2 & Negligible & Negligible & 94 \\
3 & 22 & 35 & 40 \\
4 & 29 & 20 & 37 \\
5 & 12 & 25 & 60 \\
6 & 24 & 59 & 12 \\
7 & Negligible & Negligible & 98 \\
8 & 33 & 32 & 29 \\
9 & 34 & 31 & 29 \\
\hline
\end{tabular}


Table 3. Thorium and radium activities in water samples along Jucar river

\begin{tabular}{rccccc}
\hline ID. & $\begin{array}{c}{ }^{228} \mathrm{Th}, \\
\mathrm{mBq} / 1\end{array}$ & $\begin{array}{c}{ }^{230} \mathrm{Th}, \\
\mathrm{mBq} / \mathrm{l}\end{array}$ & $\begin{array}{c}{ }^{232} \mathrm{Th}, \\
\mathrm{mBq} / 1\end{array}$ & $\begin{array}{c}{ }^{226} \mathrm{Ra}, \\
\mathrm{mBq} / 1\end{array}$ & $\begin{array}{c}{ }^{224} \mathrm{Ra} \\
\mathrm{mBq} / \mathrm{l}\end{array}$ \\
\hline 1 & $0.33 \pm 0.02$ & $0.126 \pm 0.009$ & $0.113 \pm 0.009$ & $1.11 \pm 0.05$ & $1.60 \pm 0.14$ \\
2 & $0.19 \pm 0.02$ & $0.066 \pm 0.008$ & $0.054 \pm 0.006$ & $1.88 \pm 0.11$ & $3.7 \pm 0.3$ \\
3 & $0.39 \pm 0.03$ & $0.087 \pm 0.010$ & $0.081 \pm 0.010$ & $0.57 \pm 0.02$ & $1.01 \pm 0.06$ \\
4 & $0.50 \pm 0.04$ & $0.109 \pm 0.012$ & $0.092 \pm 0.011$ & $1.07 \pm 0.05$ & $1.10 \pm 0.08$ \\
5 & $0.42 \pm 0.04$ & $0.078 \pm 0.010$ & $0.077 \pm 0.010$ & $3.2 \pm 0.2$ & $3.7 \pm 0.4$ \\
6 & $0.28 \pm 0.02$ & $0.081 \pm 0.008$ & $0.072 \pm 0.007$ & $1.70 \pm 0.08$ & $1.77 \pm 0.17$ \\
7 & $0.23 \pm 0.02$ & $0.081 \pm 0.008$ & $0.064 \pm 0.006$ & $1.32 \pm 0.06$ & $1.81 \pm 0.14$ \\
8 & $0.23 \pm 0.02$ & $0.110 \pm 0.011$ & $0.088 \pm 0.009$ & $1.52 \pm 0.07$ & $2.7 \pm 0.2$ \\
9 & $0.39 \pm 0.04$ & $0.090 \pm 0.012$ & $0.098 \pm 0.013$ & $1.32 \pm 0.08$ & $1.9 \pm 0.2$ \\
10 & $0.43 \pm 0.05$ & $0.101 \pm 0.015$ & $0.109 \pm 0.015$ & $2.29 \pm 0.14$ & $3.0 \pm 0.3$ \\
\hline
\end{tabular}

Table 4. Thorium and radium activity ratios in water samples along Jucar river

\begin{tabular}{rccc}
\hline ID. & ${ }^{228} \mathrm{Th}^{232} \mathrm{Th}$ & ${ }^{230} \mathrm{Th}^{232} \mathrm{Th}$ & ${ }^{226} \mathrm{Ra}^{224} \mathrm{Ra}$ \\
\hline 1 & $2.9 \pm 0.4$ & $1.1 \pm 0.2$ & $0.69 \pm 0.09$ \\
2 & $3.5 \pm 0.7$ & $1.2 \pm 0.3$ & $0.51 \pm 0.07$ \\
3 & $4.8 \pm 1.0$ & $1.1 \pm 0.2$ & $0.56 \pm 0.06$ \\
4 & $5.4 \pm 1.1$ & $1.2 \pm 0.3$ & $0.97 \pm 0.11$ \\
5 & $5.4 \pm 1.2$ & $1.0 \pm 0.3$ & $0.86 \pm 0.14$ \\
6 & $3.9 \pm 0.7$ & $1.1 \pm 0.2$ & $0.96 \pm 0.14$ \\
7 & $3.6 \pm 0.5$ & $1.2 \pm 0.2$ & $0.73 \pm 0.09$ \\
8 & $2.7 \pm 0.5$ & $1.2 \pm 0.2$ & $0.56 \pm 0.08$ \\
9 & $4.0 \pm 1.0$ & $1.0 \pm 0.2$ & $0.69 \pm 0.10$ \\
10 & $3.9 \pm 1.0$ & $1.0 \pm 0.2$ & $0.76 \pm 0.11$ \\
\hline
\end{tabular}

As the background of our detection system is negligible, this counting time enables to obtain low activity errors and consequently to determine distribution factors and correlations coefficients with no significant errors. Correlations coefficients are calculated between increments of $\mathrm{x}$-data (i.e., $\mathrm{pH}_{i+1}-\mathrm{pH}_{i}$ ) and increments of y-data (i.e., ${ }^{230} \mathrm{Th}_{i+1}-{ }^{230} \mathrm{Th}_{i}$ activity if we are considering a $\mathrm{pH} / 230 \mathrm{Th}$ correlation), being $i$ and $i+1$ the sampling points (Table 1).

\section{Results and discussion}

\section{Water samples}

Thorium and radium activities in water were measured and ${ }^{230} \mathrm{Th} /{ }^{232} \mathrm{Th},{ }^{228} \mathrm{Th} /{ }^{232} \mathrm{Th}$ and ${ }^{226} \mathrm{Ra} /{ }^{224} \mathrm{Ra}$ activities ratios calculated. Results are shown in Tables 3 and 4.

Figure 2 shows the activity of each isotope of natural thorium, ${ }^{224} \mathrm{Ra},{ }^{226} \mathrm{Ra}$ and $\mathrm{pH}$ vs distance from the source of Jucar River. The same behavior can be seen for the same chemical element (i.e., an increase of the ${ }^{226} \mathrm{Ra}$ activity are associated with an increase of the ${ }^{224} \mathrm{Ra}$ activity). Nevertheless, ${ }^{228} \mathrm{Th}$ activity is significantly greater than the activity of the other thorium isotopes analysed. This can be explained if we consider ${ }^{228} \mathrm{Ra}$ solubility (precursor of ${ }^{228} \mathrm{Th}$ ) which is greater than solubility of the other thorium isotopes. ${ }^{228} \mathrm{Ra}$ remains in water and produces by $\beta$-decay ${ }^{228} \mathrm{Th}$ which remains also in water. The above process produce ${ }^{228} \mathrm{Th}^{232} \mathrm{Th}$ activity ratios greater than one while ${ }^{230} \mathrm{Th} /{ }^{232} \mathrm{Th}$ is nearly one (Table 4 ). Radium activities are one order of magnitude higher than thorium activities, due as explained to the greater solubility of radium isotopes in water. The possibility of a correlation between $\mathrm{pH}$ and radium activity has been studied. We have found a Pearson's correlation coefficient of $r=0.72$. This correlation, being significant, is not so strong as the uranium correlation we found previously for uranium $/ \mathrm{pH}$ in Jucar river. ${ }^{4}$ However, thorium correlation activity with $\mathrm{pH}$ was not significant. This is probably due to the low solubility of thorium in water. This implies that thorium activity in water is so poor that it is not possible to conclude about thorium correlation with $\mathrm{pH}$ in water samples.

In Fig. $3 \mathrm{Th}$ and $\mathrm{Ra}$ activity ratios are shown together with the variation of the $\mathrm{pH}$. No significant correlation has been found between $\mathrm{Th}$ and $\mathrm{Ra}$ activity ratios and $\mathrm{pH}\left(r=-0.33\right.$ for ${ }^{228} \mathrm{Th} /{ }^{232} \mathrm{Th}, r=-0.31$ for ${ }^{230} \mathrm{Th} /{ }^{232} \mathrm{Th}$ and $r=-0.50$ for ${ }^{226} \mathrm{Ra} / 224 \mathrm{Ra}$ ). We have not found any correlation between conductivity or temperature and radium/thorium water activities.

\section{Sediment samples}

A similar study has been carried out for sediments. Table 5 shows thorium and radium activities while Table 6 shows ${ }^{230} \mathrm{Th} /{ }^{232} \mathrm{Th}$ and ${ }^{228} \mathrm{Th} /{ }^{232} \mathrm{Th}$ activity ratios. It was not possible to take sediment sample in the last point (No. 10, Fig. 1), because the river flows into an artificial channel. 

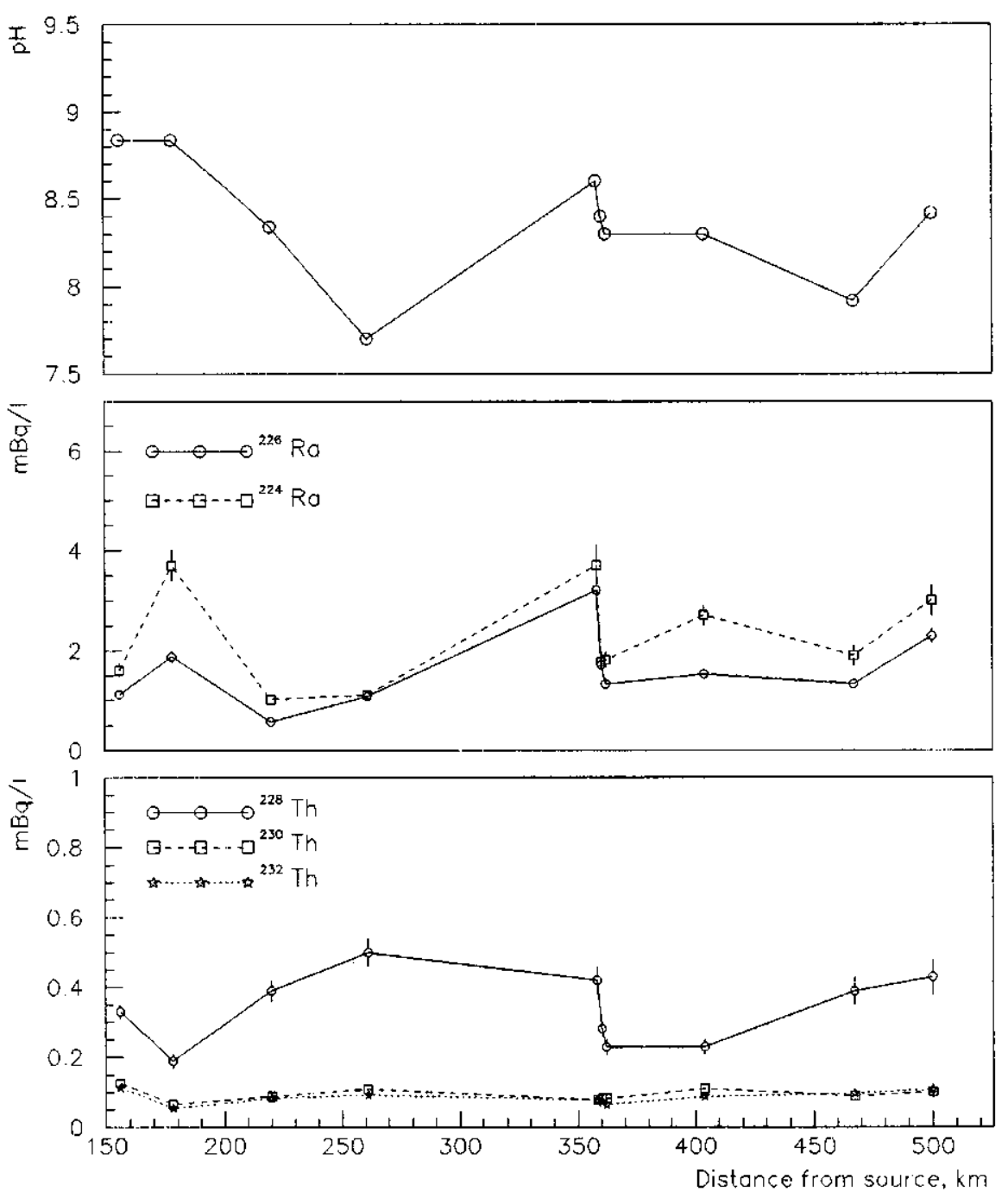

Fig. 2. Thorium, radium activities and $\mathrm{pH}$ in water samples along Jucar river

As in the uranium case, ${ }^{4}$ it can be seen that thorium and radium activities do not depend on the sediment size for the samples and the sizes condidered in this work. Only for ${ }^{226} \mathrm{Ra}$ activities and for grain size $\leq 0.063 \mathrm{~cm}$ we observe a light decrease in activity, but this is not significant ( $\mathrm{F} 3$ in table 5) if the error limits are considered. For this grain size (F3: clay, silt and medium sand) the "surface/volume" ratio is the highest. This implies that for this grain size the "washing and leaching" effect of the water over sediments is more effective than for the other sizes studied. This behavior is similar to that found for uranium in a previous work. ${ }^{4}$ No effect of grain size has been found for activity ratios (Table 6).

It is very important to note that thorium is mainly located in sediments because of its low solubility in water. This produces that the parameters considered $(\mathrm{pH}$, temperature and conductivity) do not affect thorium activity for the variation range considered in this work.

In Fig. 4 it is visible that ${ }^{228} \mathrm{Th},{ }^{230} \mathrm{Th},{ }^{232} \mathrm{Th}$ and ${ }^{226} \mathrm{Ra}$ activities in sediment samples have a quite similar behavior, although ${ }^{226} \mathrm{Ra}$ activity presents sligh differences from this parallel behavior.

It is well established 15,16 and has also been experimentally corroborated 17,18 that botton sediments and suspended solids play an important role in the migration of radium in surface waters. The mechanism and principal laws of the interaction of radium with solid phases in the waters are insufficiently known and do not allow reliable interpretation of the data on radium migration in real systems. No significant correlation has been found between temperature, $\mathrm{pH}$ or conductivity and Th(Ra) activities in sediment samples. We found a correlation coefficient of $r=-0.46$ between $\mathrm{pH}$ and ${ }^{226} \mathrm{Ra}$ for FT (without sieve) size sediment, being nearly 
zero this correlation coefficient for total thorium activity and $\mathrm{pH}(r=-0.05)$. However, in laboratory conditions a correlation between $\mathrm{pH}$ and radium adsorption in sediments has been found. ${ }^{19}$ The lack of such dependence in our measurements could be explained if we consider that our $\mathrm{pH}$ range (7.7-8.84) is smaller than that considered in Reference 19 ( $\mathrm{pH}$ between 2-10).

\section{Suspended matter samples}

${ }^{230} \mathrm{Th},{ }^{232} \mathrm{Th},{ }^{228} \mathrm{Th}$ and ${ }^{226} \mathrm{Ra}$ activities were measured in suspended matter and ${ }^{228} \mathrm{Th} /{ }^{232} \mathrm{Th}$ and ${ }^{230} \mathrm{Th} /{ }^{232} \mathrm{Th}$ activity ratios were calculated (Table 7 ).

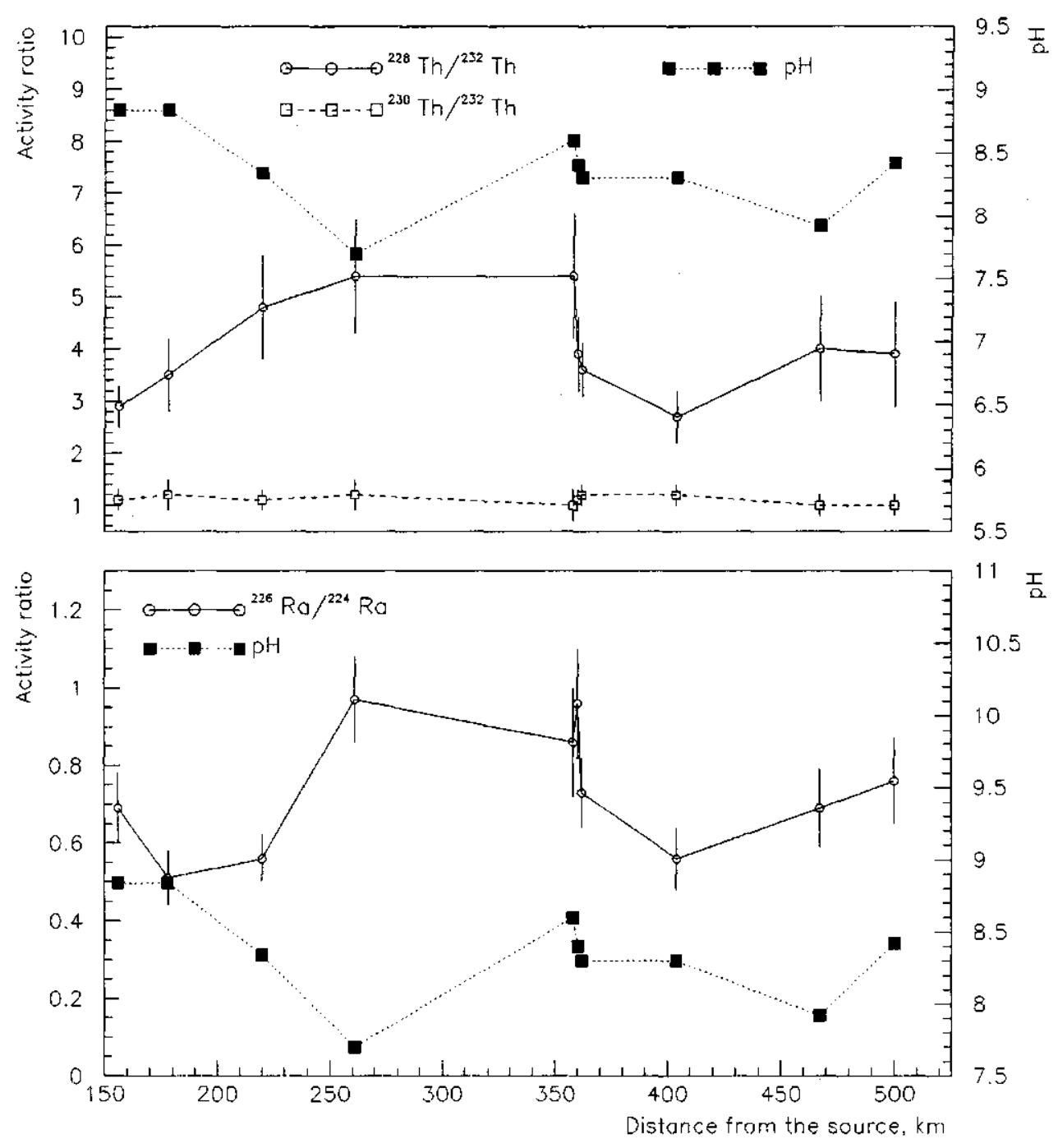

Fig. 3. Thorium, radium activity ratios and $\mathrm{pH}$ in water samples along Jucar river 
Table 5. Thorium and radium activities in sediments along Jucar river; F1: grain size between 0.6 and $0.143 \mathrm{~cm}$; F2: grain size between 0.143 and $0.063 \mathrm{~cm} ; \mathrm{F} 3$ : grain size $\leq 0.063 \mathrm{~cm}$;

FT: sediment all without sieving

\begin{tabular}{rrrrrr}
\hline in. & Grain size & $\begin{array}{c}{ }^{232} \mathrm{Th}, \\
\mathrm{mBq} / \mathrm{g}\end{array}$ & $\begin{array}{c}{ }^{230} \mathrm{Th}, \\
\mathrm{mBq} / \mathrm{g}\end{array}$ & $\begin{array}{c}{ }^{228} \mathrm{Th}, \\
\mathrm{mBq} / \mathrm{g}\end{array}$ & $\begin{array}{c}{ }^{226} \mathrm{Ra}, \\
\mathrm{mBq} / \mathrm{g}\end{array}$ \\
\hline 1 & F1 & $22.1 \pm 0.8$ & $22.4 \pm 0.8$ & $23.6 \pm 0.9$ & $14.8 \pm 0.4$ \\
& FT & $22.1 \pm 0.9$ & $22.9 \pm 0.9$ & $22.5 \pm 0.9$ & $14.4 \pm 0.4$ \\
2 & F3 & $18.2 \pm 0.7$ & $18.4 \pm 0.7$ & $21.3 \pm 0.8$ & $11.9 \pm 0.4$ \\
& FT & $17.6 \pm 0.7$ & $19.5 \pm 0.8$ & $20.4 \pm 0.8$ & $12.2 \pm 0.4$ \\
3 & F1 & $35.8 \pm 1.3$ & $39.4 \pm 1.2$ & $35.8 \pm 1.2$ & $33.3 \pm 0.9$ \\
& F2 & $35.9 \pm 1.2$ & $37.6 \pm 1.2$ & $35.4 \pm 1.2$ & $32.5 \pm 0.9$ \\
& F3 & $35.7 \pm 1.6$ & $37.0 \pm 1.5$ & $32.6 \pm 1.5$ & $32.5 \pm 1.1$ \\
& FT & $35.8 \pm 1.0$ & $39.1 \pm 1.1$ & $35.0 \pm 1.0$ & $32.8 \pm 0.8$ \\
4 & F1 & $18.6 \pm 0.6$ & $19.3 \pm 0.5$ & $21.6 \pm 0.6$ & $21.4 \pm 0.8$ \\
& F2 & $18.6 \pm 0.6$ & $19.5 \pm 0.7$ & $21.8 \pm 0.7$ & $21.2 \pm 0.5$ \\
& F3 & $18.9 \pm 0.7$ & $19.4 \pm 0.7$ & $21.4 \pm 0.8$ & $19.8 \pm 0.8$ \\
5 & FT & $18.8 \pm 0.8$ & $19.4 \pm 0.8$ & $22.1 \pm 0.9$ & $21.3 \pm 0.4$ \\
& F1 & $19.7 \pm 0.9$ & $19.7 \pm 0.9$ & $26.3 \pm 1.0$ & $10.0 \pm 0.2$ \\
& F2 & $18.7 \pm 0.7$ & $18.8 \pm 0.7$ & $23.3 \pm 0.8$ & $9.2 \pm 0.3$ \\
& F3 & $20.5 \pm 0.7$ & $17.1 \pm 0.6$ & $24.1 \pm 0.9$ & $9.2 \pm 0.2$ \\
6 & FT & $18.1 \pm 0.8$ & $18.1 \pm 0.8$ & $24.0 \pm 1.0$ & $9.5 \pm 0.2$ \\
& F1 & $33 \pm 2$ & $34 \pm 2$ & $33 \pm 2$ & $24.0 \pm 0.5$ \\
& F2 & $34 \pm 2$ & $35 \pm 2$ & $31.7 \pm 1.5$ & $24.0 \pm 0.6$ \\
& F3 & $32.4 \pm 1.0$ & $33.0 \pm 1.0$ & $34.0 \pm 1.1$ & $23.7 \pm 0.8$ \\
7 & FT & $33 \pm 2$ & $33 \pm 2$ & $33 \pm 2$ & $24.0 \pm 0.7$ \\
& F3 & $24.0 \pm 1.2$ & $26.5 \pm 1.3$ & $22.6 \pm 1.0$ & $17.6 \pm 0.3$ \\
8 & FT & $24.0 \pm 1.3$ & $25.9 \pm 1.4$ & $24.0 \pm 1.3$ & $17.8 \pm 0.3$ \\
& F1 & $17.8 \pm 1.0$ & $17.9 \pm 1.0$ & $16.3 \pm 0.9$ & $6.0 \pm 0.2$ \\
& F2 & $17.1 \pm 0.8$ & $17.2 \pm 0.8$ & $16.5 \pm 0.7$ & $5.7 \pm 0.2$ \\
& F3 & $14.9 \pm 0.8$ & $14.9 \pm 0.8$ & $13.5 \pm 0.7$ & $5.6 \pm 0.2$ \\
& FT & $17.9 \pm 0.7$ & $17.9 \pm 0.7$ & $15.7 \pm 0.6$ & $5.8 \pm 0.2$ \\
& F1 & $22.9 \pm 1.0$ & $21.9 \pm 1.0$ & $22.9 \pm 1.0$ & $17.9 \pm 0.4$ \\
& F2 & $22.6 \pm 1.1$ & $23.1 \pm 1.4$ & $22.5 \pm 1.3$ & $17.2 \pm 0.4$ \\
& F3 & $23.4 \pm 1.1$ & $22.0 \pm 1.1$ & $23.5 \pm 1.1$ & $16.0 \pm 0.4$ \\
& FT & $22.6 \pm 1.2$ & $23.6 \pm 1.2$ & $21.2 \pm 1.2$ & $17.4 \pm 0.5$ \\
\hline
\end{tabular}

Figure 5 shows thorium and radium activities in suspended matter. Values of suspended matter activity are very similar to those in sediment measurements. However, ${ }^{230} \mathrm{Th},{ }^{232} \mathrm{Th},{ }^{228} \mathrm{Th}$ and ${ }^{226} \mathrm{Ra}$ activities behavior (Fig. 5) is not so similar among them as that we have found for sediment samples (Fig, 4). No significant correlation between $\mathrm{pH}$, temperature or conductivity and $\mathrm{Th}(\mathrm{Ra})$ activities has been found for suspended matter samples (correlation coefficient $r=0.38$ for $\mathrm{pH}$ and ${ }^{226} \mathrm{Ra}$ while for ${ }^{228} \mathrm{Th} r=0.66$ ).

${ }^{230} \mathrm{Th} /{ }^{232} \mathrm{Th}$ activity ratios in suspended matter are near to one, as in the case of sediments and water samples, while for ${ }^{228} \mathrm{Th} / 232 \mathrm{Th}$ ratios the values we have found for suspended matter $\left({ }^{228} \mathrm{Th} /{ }^{232} \mathrm{Th}\right.$ mean value $\approx 1.5$ ) are near to the sediments samples ratios we have measured $\left({ }^{228} \mathrm{Th} /{ }^{232} \mathrm{Th}\right.$ mean value $\left.\approx 1\right)$ and very far from those we found for water samples $\left({ }^{228} \mathrm{Th} /{ }^{232} \mathrm{Th}\right.$ mean value $\approx 4$ ). This is very important as it allows us to conclude that thorium activity in suspended matter could mainly come from sediment and not by washing of sediments itself. That is, the activity of thorium in suspended matter could come from the motion of sediments, by resuspension of small particles of sediments due to the water motion. Finally, no significant correlation has been found between $\mathrm{pH}$, temperature or conductivity and ${ }^{228} \mathrm{Th} / 232 \mathrm{Th}$ activity ratios, the correlation coefficient being nearly zero (i.e., $r=0.05$ if $\mathrm{pH}$ and ${ }^{228} \mathrm{Th} / 232 \mathrm{Th}$ correlation is considered).

\section{Distribution factors}

Distribution factors between suspended matter and water along Jucar river have been calculated as the ratio between activity in suspended matter and water by using the following equation:

$$
K_{d}^{i}=\frac{A_{\text {Susp }}^{i} \times 10^{\hat{3}}}{A_{\text {Water }}^{i}}
$$

where $A_{S u s p}^{i}$ is the suspended matter activity in $\mathrm{mBq} / \mathrm{g}$ and $A_{\text {Water }}^{i}$ the water activity in $\mathrm{mBq} / \mathrm{l}$ due to radionuclide $i$. 
Table 6. Thorium activity ratios in sediments along Jucar river; Fl: grain size between 0.6 and $0.143 \mathrm{~cm} ; \mathrm{F} 2$ : grain size between 0.143 and $0.063 \mathrm{~cm} ; \mathrm{F} 3$; grain size $\leq 0.063 \mathrm{~cm}$; FT: sediment all without sieving

\begin{tabular}{|c|c|c|c|}
\hline ID. & Grain size & ${ }^{230} \mathrm{Th} /{ }^{232} \mathrm{Th}$ & ${ }^{228} \mathrm{Th} /{ }^{232} \mathrm{Th}$ \\
\hline \multirow[t]{2}{*}{1} & $\mathrm{~F} 1$ & $1.01 \pm 0.07$ & $1.07 \pm 0.08$ \\
\hline & FT & $1.04 \pm 0.09$ & $1.02 \pm 0.08$ \\
\hline \multirow[t]{2}{*}{2} & F3 & $1.01 \pm 0.09$ & $1.17 \pm 0.09$ \\
\hline & $\mathrm{FT}$ & $1.11 \pm 0.07$ & $1.16 \pm 0.08$ \\
\hline \multirow[t]{4}{*}{3} & F1 & $1.10 \pm 0.09$ & $1.00 \pm 0.07$ \\
\hline & $\mathrm{F} 2$ & $1.05 \pm 0.07$ & $0.99 \pm 0.07$ \\
\hline & F3 & $1.04 \pm 0.10$ & $0.91 \pm 0.08$ \\
\hline & FT & $1.09 \pm 0.06$ & $0.98 \pm 0.05$ \\
\hline \multirow[t]{4}{*}{4} & $\mathrm{~F} 1$ & $1.04 \pm 0.06$ & $1.16 \pm 0.06$ \\
\hline & $\mathrm{F} 2$ & $1.05 \pm 0.07$ & $1.17 \pm 0.08$ \\
\hline & F3 & $1.03 \pm 0.08$ & $1.13 \pm 0.09$ \\
\hline & $\mathrm{FT}$ & $1.03 \pm 0.08$ & $1.18 \pm 0.09$ \\
\hline \multirow[t]{4}{*}{5} & $\mathrm{~F} 1$ & $1.00 \pm 0.09$ & $1.34 \pm 0.10$ \\
\hline & $\mathrm{F} 2$ & $1.00 \pm 0.07$ & $1.25 \pm 0.09$ \\
\hline & F3 & $0.83 \pm 0.06$ & $1.18 \pm 0.08$ \\
\hline & FT & $1.00 \pm 0.09$ & $1.33 \pm 0.11$ \\
\hline \multirow[t]{4}{*}{6} & F1 & $1.03 \pm 0.13$ & $1.00 \pm 0.13$ \\
\hline & $\mathrm{F} 2$ & $1.03 \pm 0.10$ & $0.93 \pm 0.09$ \\
\hline & F3 & $1.02 \pm 0.06$ & $1.05 \pm 0.07$ \\
\hline & FT & $1.00 \pm 0.11$ & $1.00 \pm 0.11$ \\
\hline \multirow[t]{2}{*}{7} & F3 & $1.10 \pm 0.11$ & $0.94 \pm 0.09$ \\
\hline & FT & $1.08 \pm 0.12$ & $1.00 \pm 0.11$ \\
\hline \multirow[t]{4}{*}{8} & Fl & $1.01 \pm 0.11$ & $0.92 \pm 0.11$ \\
\hline & $\mathrm{F} 2$ & $1.01 \pm 0.09$ & $0.96 \pm 0.09$ \\
\hline & $\mathrm{F} 3$ & $1.00 \pm 0.10$ & $0.91 \pm 0.09$ \\
\hline & FT & $1.00 \pm 0.08$ & $0.88 \pm 0.07$ \\
\hline \multirow[t]{4}{*}{9} & F1 & $0.96 \pm 0.09$ & $1.00 \pm 0.09$ \\
\hline & F2 & $1.02 \pm 0.12$ & $1.00 \pm 0.12$ \\
\hline & F3 & $0.94 \pm 0.09$ & $1.00 \pm 0.09$ \\
\hline & FT & $1.04 \pm 0.11$ & $0.94 \pm 0.10$ \\
\hline
\end{tabular}

Distribution factor $K_{d}^{i}$ represents the adsorption degree of a radionuclide in the suspended matter and, although it implies equilibrium conditions, it is widely used in a much more extensive sense in non equilibrium situations. Some authors consider distribution factors sediment-water ${ }^{20}$ instead of suspended matter-water ratios. However, in our case we have used "suspended matter-water" data as these ratios should be more representative than those coming from "sediment-water" data. Table 8 presents the distribution factors we have calculated for the samples analysed in this work.

${ }^{232} \mathrm{Th}$ and ${ }^{230} \mathrm{Th}$ distribution factors are nearly equal within the error limits and about three times higher than those obtained for ${ }^{228} \mathrm{Th}$ (Fig. 6). This is due to the fact that ${ }^{228} \mathrm{Th}$ water samples activities are three times greater than ${ }^{232} \mathrm{Th}$ and ${ }^{230} \mathrm{Th}$ activities in water (Table 3), while suspended matter activity for thorium isotopes is of the same order (Table 7). As explained before this can be understood in terms of ${ }^{228} \mathrm{Ra}$ solubility (precursor of ${ }^{228} \mathrm{Th}$ ) which is greater than the solubility of other thorium isotopes.

In general, distribution factors we have found that ${ }^{226} \mathrm{Ra}$ and thorium isotopes fulfil the relationship:

$$
K_{d}^{\mathrm{Th}-232} \approx K_{d}^{\mathrm{Th}-230} \approx 3 \times K_{d}^{\mathrm{Th}-228} \approx 10 \times K_{d}^{\mathrm{Ra}-226}
$$

Distribution factors for ${ }^{226} \mathrm{Ra}$ with regard to thorium isotopes values show the higher water solubility of radium than thorium, as suspended matter activities are of the same order for thorium and radium (Table 7). We have not found any significant correlation between $\mathrm{pH}$, conductivity or temperature and distribution factors for the samples analyzed in this work (i.e., if $\mathrm{pH}$ is considered we found a correlation coefficient $r=0.6$ for ${ }^{230} \mathrm{Th}, r \approx 0.35$ for ${ }^{228} \mathrm{Th}$ and ${ }^{232} \mathrm{Th}$ and nearly zero for ${ }^{226} \mathrm{Ra}$ ).

The values of the distribution factors found for Jucar river are in the range obtained by other authors ${ }^{20-22}$ for other systems. Nevertheless, the variation range for distribution factors is very large, as this parameter depends on a set of parameters as $\mathrm{pH}$, temperature, sediment size, salinity which vary from one system to another, yielding a great variability of the distribution factors. 
F. SANCHEZ, M. J. RODRIGUEZ-ALVAREZ: EFFECT OF $\mathrm{pH}$, TEMPERATURE, CONDUCTIVTTY AND SEDIMENT SIZE

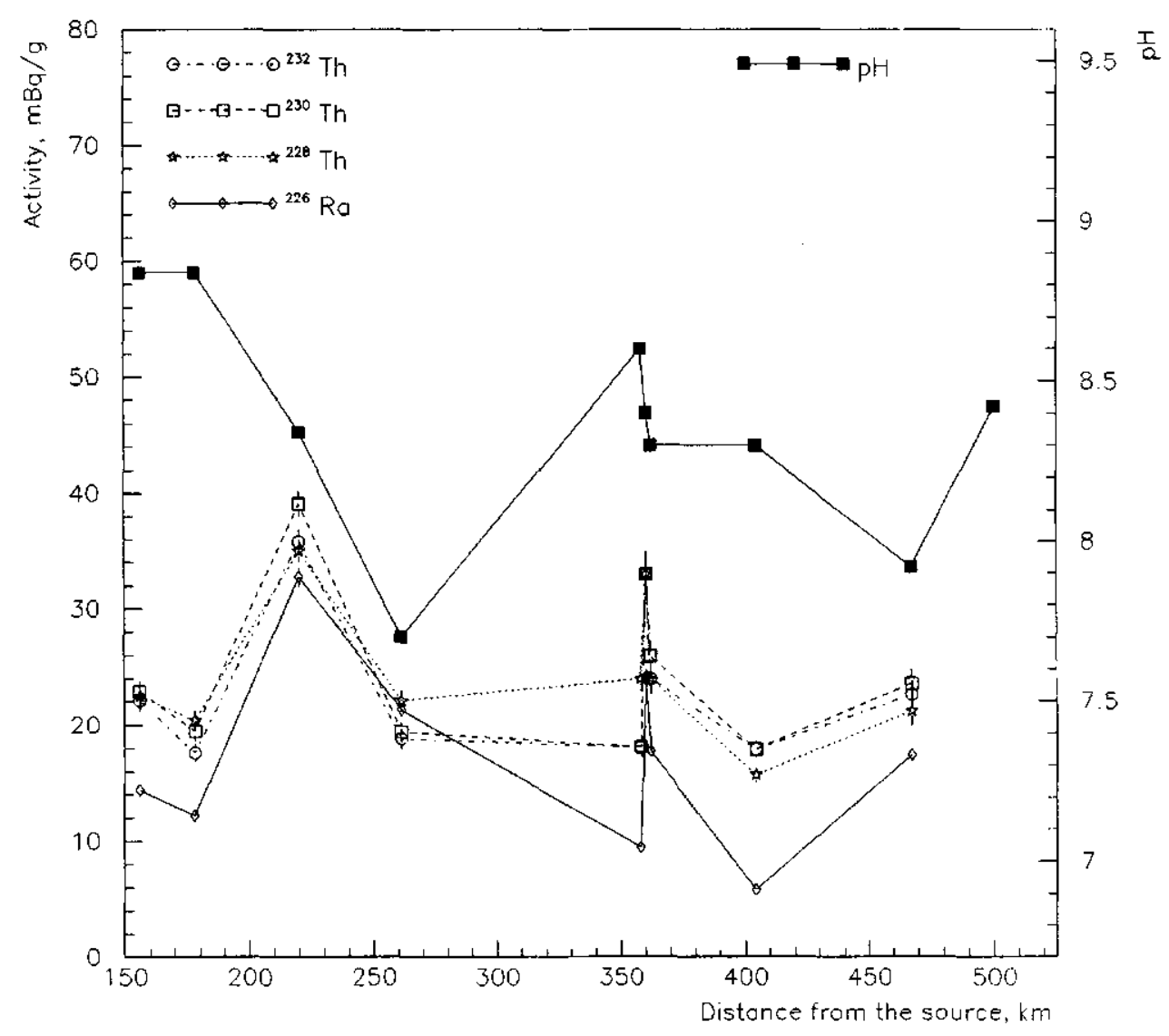

Fig. 4. Thorium, radium activities and $\mathrm{pH}$ in sediment samples along Jucar river

Table 7. Thorium and radium activities and activity ratio in suspended matter along Jucar river

\begin{tabular}{rcccccc}
\hline ID. & $\begin{array}{c}{ }^{228} \mathrm{Th}, \\
\mathrm{mBq} / \mathrm{g}\end{array}$ & $\begin{array}{c}{ }^{230} \mathrm{Th}, \\
\mathrm{mBq} / \mathrm{g}\end{array}$ & $\begin{array}{c}{ }^{232} \mathrm{Th}, \\
\mathrm{mBq} / \mathrm{g}\end{array}$ & $\begin{array}{c}{ }^{226} \mathrm{Ra}, \\
\mathrm{mBq} / \mathrm{g}\end{array}$ & ${ }^{230} \mathrm{Th}^{232} \mathrm{Th}$ & ${ }^{228} \mathrm{Th} /{ }^{232} \mathrm{Th}$ \\
\hline 1 & $15.6 \pm 1.4$ & $20 \pm 2$ & $15.5 \pm 1.4$ & $20.4 \pm 1.2$ & $1.3 \pm 0.2$ & $1.0 \pm 0.2$ \\
2 & $27 \pm 2$ & $19 \pm 2$ & $17.0 \pm 1.5$ & $15.7 \pm 1.4$ & $1.1 \pm 0.2$ & $1.6 \pm 0.3$ \\
3 & $16.5 \pm 1.2$ & $11.4 \pm 0.9$ & $10.1 \pm 0.8$ & $13.5 \pm 0.9$ & $1.1 \pm 0.2$ & $1.6 \pm 0.3$ \\
4 & $15.2 \pm 1.5$ & $11.8 \pm 1.2$ & $10.2 \pm 1.0$ & $10.0 \pm 0.8$ & $1.1 \pm 0.2$ & $1.5 \pm 0.3$ \\
5 & $26 \pm 2$ & $22 \pm 2$ & $18 \pm 2$ & $20.2 \pm 1.1$ & $1.2 \pm 0.2$ & $1.4 \pm 0.2$ \\
6 & $20.5 \pm 1.4$ & $13.7 \pm 1.0$ & $12.9 \pm 0.9$ & $16.9 \pm 1.1$ & $1.06 \pm 0.15$ & $1.6 \pm 0.2$ \\
7 & $26 \pm 2$ & $31 \pm 2$ & $27 \pm 2$ & $32 \pm 2$ & $1.1 \pm 0.2$ & $0.96 \pm 0.15$ \\
8 & $34 \pm 3$ & $24 \pm 2$ & $18 \pm 2$ & $32.6 \pm 1.0$ & $1.3 \pm 0.2$ & $1.9 \pm 0.3$ \\
9 & $21.3 \pm 1.3$ & $14.3 \pm 0.9$ & $13.6 \pm 0.9$ & $14.7 \pm 1.0$ & $1.05 \pm 0.14$ & $1.6 \pm 0.2$ \\
10 & $24 \pm 2$ & $18.2 \pm 1.3$ & $16.4 \pm 1.1$ & $7.5 \pm 0.8$ & $1.1 \pm 0.2$ & $1.5 \pm 0.2$ \\
\hline
\end{tabular}


F. SANCHEZ, M. J. RODRIGUEZ-ALVAREZ: EFFECT OF pH, TEMPERATURE, CONDUCTIVITY AND SEDMMENT SLZE

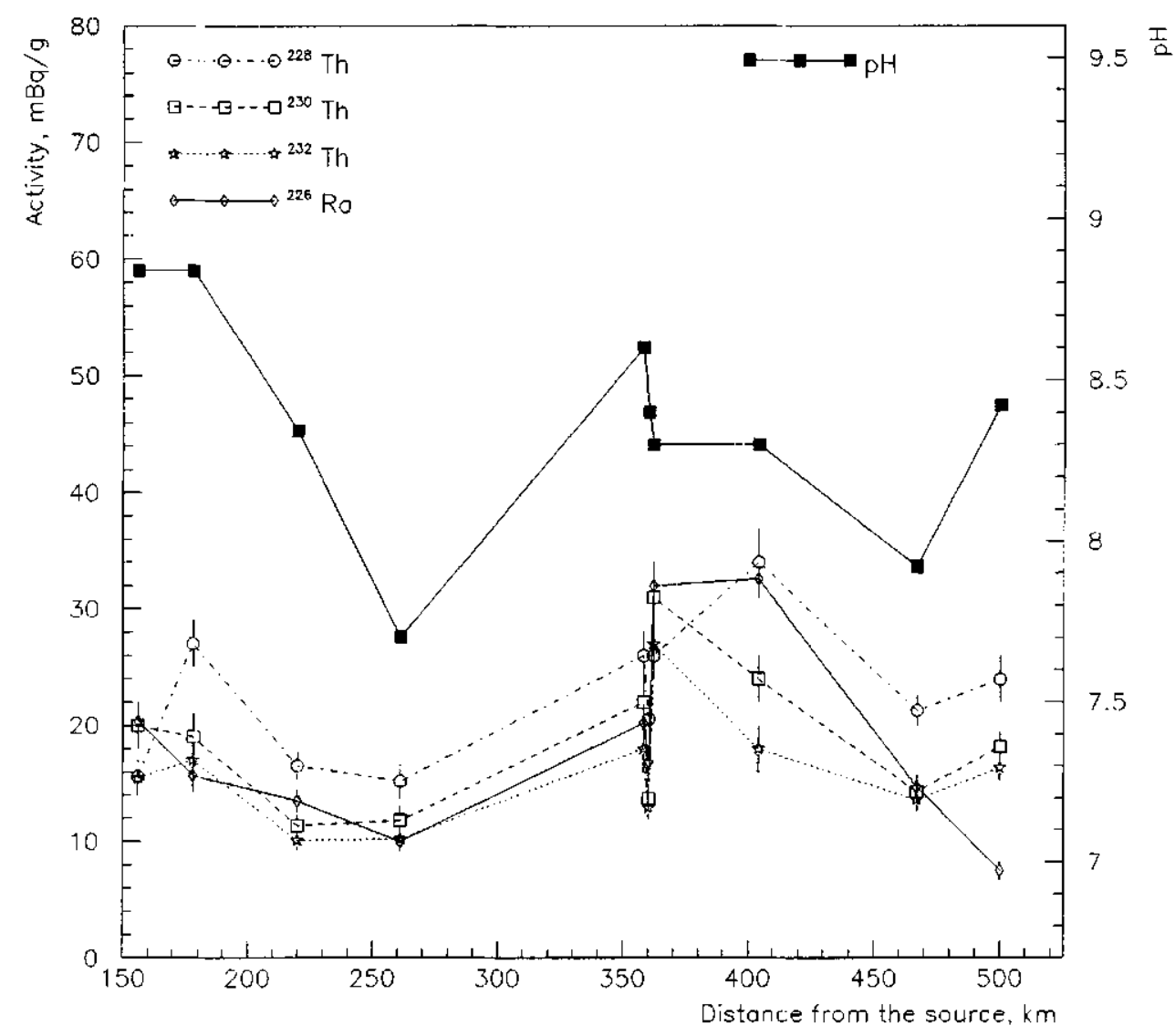

Fig. 5. Thorium, radium activities and $\mathrm{pH}$ in suspended matter samples along Jucar river

Table 8. Distribution factors for thorium and ${ }^{226} \mathrm{Ra}$ isotopes along Jucar river

\begin{tabular}{rrrrr}
\hline ID. & $\begin{array}{c}{ }^{228} \mathrm{Th}, \\
1 / \mathrm{kg}\end{array}$ & $\begin{array}{c}{ }^{230} \mathrm{Th}, \\
1 / \mathrm{kg}\end{array}$ & $\begin{array}{c}{ }^{232} \mathrm{Th}, \\
1 / \mathrm{kg}\end{array}$ & $\begin{array}{c}{ }^{226} \mathrm{Ra}, \\
1 / \mathrm{kg}\end{array}$ \\
\hline 1 & $(47 \pm 7) 10^{3}$ & $(16 \pm 3) 10^{4}$ & $(14 \pm 2) 10^{4}$ & $(18.4 \pm 1.7) 10^{3}$ \\
2 & $(14 \pm 2) 10^{4}$ & $(29 \pm 7) 10^{4}$ & $(31 \pm 6) 10^{4}$ & $(8.4 \pm 0.9) 10^{3}$ \\
3 & $(42 \pm 6) 10^{3}$ & $(13 \pm 2) 10^{4}$ & $(12 \pm 2) 10^{4}$ & $(24 \pm 2) 10^{3}$ \\
4 & $(30 \pm 5) 10^{3}$ & $(10 \pm 2) 10^{4}$ & $(11 \pm 2) 10^{4}$ & $(9.3 \pm 1.2) 10^{3}$ \\
5 & $(61.9 \pm 1.1) 10^{3}$ & $(28 \pm 6) 10^{4}$ & $(23 \pm 6) 10^{4}$ & $(6.3 \pm 0.7) 10^{3}$ \\
6 & $(73.2 \pm 1.0) 10^{3}$ & $(17 \pm 3) 10^{4}$ & $(18 \pm 3) 10^{4}$ & $(9.9 \pm 1.8) 10^{3}$ \\
7 & $(11.3 \pm 1.8) 10^{3}$ & $(38 \pm 6) 10^{4}$ & $(42 \pm 7) 10^{4}$ & $(24.2 \pm 1.9) 10^{3}$ \\
8 & $(15 \pm 3) 10^{3}$ & $(29 \pm 4) 10^{4}$ & $(20 \pm 4) 10^{4}$ & $(21.4 \pm 1.7) 10^{3}$ \\
9 & $(55 \pm 9) 10^{3}$ & $(16 \pm 3) 10^{4}$ & $(14 \pm 3) 10^{4}$ & $(11.1 \pm 1.4) 10^{3}$ \\
10 & $(55.8 \pm 1.1) 10^{3}$ & $(18 \pm 4) 10^{4}$ & $(15 \pm 3) 10^{4}$ & $(3.3 \pm 0.5) 10^{3}$ \\
\hline
\end{tabular}



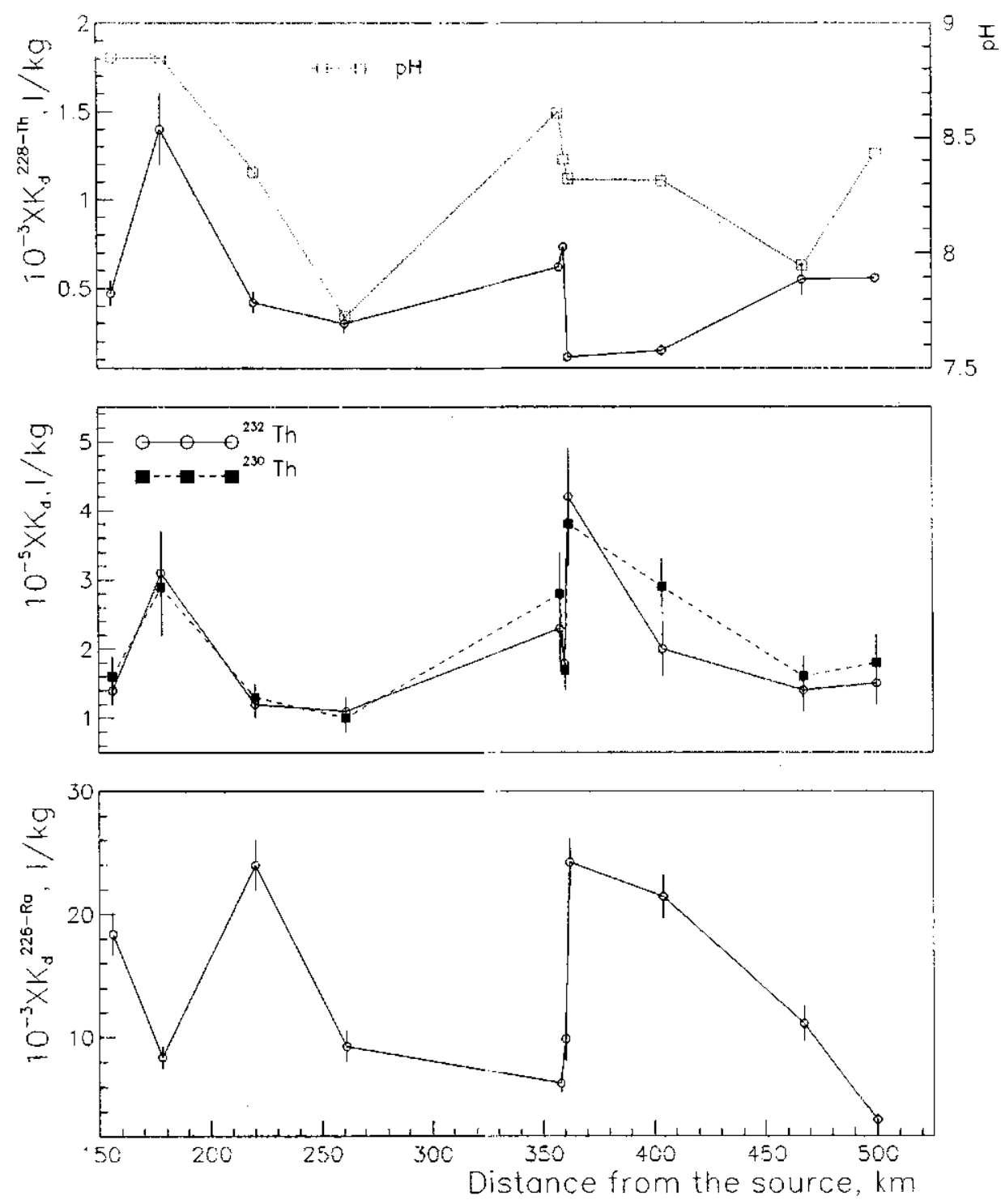

Fig. 6. Distribution factor $\left(k_{d}\right)$ for ${ }^{232} \mathrm{Th},{ }^{228} \mathrm{Th},{ }^{230} \mathrm{Th}$ and ${ }^{226} \mathrm{Ra}$ along Jucar river together with pH variation

\section{Conclusions}

We have measured by $\alpha$-spectrometry thorium and radium activities in water, suspended matter and sediments samples along the Jucar river (East of Spain). In these measurements we have used a low level $\alpha$-spectrometry procedure recently developed in our laboratory. ${ }^{5}$ As with uranium previously studied, ${ }^{2}$ we have not found any evidence of thorium or radium releases from Cofrentes Nuclear Power Plant.

We have not found any significant correlation between thorium activity in water and $\mathrm{pH}$. This could be explained in terms of the very low solubility of thorium in water which implies that $\mathrm{pH}$ or conductivity variations do not affect thorium content of water. However, this is not the case for radium activity in water and $\mathrm{pH}$ where a Pearson's correlation coefficient $r=0.72$ has been found. Although this correlation is significant but not so strong as the uranium $/ \mathrm{pH}$ correlation we found previously along Jucar river for the same samples. ${ }^{4}$ No other significant correlations between the parameters considered in this work ( $\mathrm{pH}$, temperature and conductivity) and thorium or radium activities (or activity ratios) in sediment and suspended matter has been found. We have found that thorium and radium activities (and the related activity ratios) do not depend on the sediment size for the 
samples and the sizes considered in this work. The values we obtain for ${ }^{228} \mathrm{Th} /{ }^{232} \mathrm{Th}$ activity ratios in suspended matter, sediments and water allow to conclude that thorium activity in suspended matter could mainly come from sediments and not by washing of sediments itself.

Finally, distribution factors between suspended matter and water have been calculated. We have not found any significant correlation between $\mathrm{pH}$, conductivity or temperature and distribution factors for the samples analyzed in this work. The values we have found for the distribution factors will allow us to develop a mathematical model for Jucar river which will describe the dynamic behavior of these radionuclides along this river.

One of us (M. J. R.-A.) is grateful to Institución Valenciana de Estudios e Investigación, Spain (I.V.E.I.) for a fellowship.

\section{References}

1. M. J. RODRIGUEZ-ALVAREZ, F. SANCHEZ, J. Radioanal. Nucl. Chem., 191 (1995) 3.

2. M. J. RoDRiguez-Alvarfz, F. SÁNCHEZ, E. NAVARRo, Proc. 3rd Intern. Summer School, Huelva Spain, M. GARCIA-LEON and G. MADURGA (Eds), World Scientific, Singapore, 1994, p. 549.

3. M. J. RODRIGUEZ-ALVAREZ, Medidas de Uranio, Torio y Radio en Muestras Ambientales por Espectrometría alfa. Aplicación a un Modelo Unidimensional de Transporte de Radionúclidos en el Río Júcar. PhD Thesis, Universidad de Valencia, Spain, 1998 (in Spanish).

4. M. J. RODRIGUEZ-ALVAREZ, F. SÁNCHEZ, J. Radioanal. Nucl. Chem., to be published.
5. M. J. RODRIGUEZ-ALVAREZ, F. SANCHEZ, J. Radioanal. Nucl. Chem., 190 (1995) 113.

6. Uranium Disequilibrium Series. Applications to Environmental Problems, M. IVANOVICH and R. S. HaRMON (Eds), Clarendon Press, Oxford, 1992.

7. A. MARTINEZ-AGUIRRE, M. GARCÍA-LFón, J. Radioanal. Nucl. Chem., 155 (1991) 97.

8. R. PERIAÑEZ, A. MARTINEZ-AGUIRRe, J. Environ. Radiact., 35 (1997) No. 3, 281

9. P. BENEŠ, P. PICAT, M. ČERNIK, J. M. QUNAULT, J. Radioanal Nucl. Chem., 159 (1992) 175

10. P. BenEš, M. CERNiK, J. Radioanal. Nucl. Chem., 159 (1992) 187

11. N. A. TALVITIE, Anal. Chem., 44 (1972) 280.

12. R. GARCAA-TENORЮ, M. GARCIA-LFÓN, M. MADURGA C. PIAZZA, Anal. Física B, 82 (1986) 238.

13. L. HAllstadrus, Nucl. Instrum. Meth. Phys. Res., 223 (1984) 266

14. G. J. HANCOCK, P. MARTN, Appl. Radiation Isotopes, 40 (1989) 63.

15. USEPA, Potential Health and Environmental Hazard of Uranium Mine Wastes, EPA 520/1-83-007, U.S. Environmental Protection Agency, Washington, 1983

16. P. BENES, Physico-chemical Forms and Migration in Continental Waters of Radium from Uranium Mining and Milling, in: Environmental Migration of Long-lived Radionuclides, IAEA, Vienna, 1982, p. 3

17. F. SEBESTA, Environ. Sci. Technol., 15 (1981) 71

18. P. BENEŠ, Water Res., 17 (1983) 619.

19. P. BENEŠ, P. STREJC, J. Radioanal. Nucl. Chem., 99 (1986) 407.

20. T. H. SIBLEY, C. MYTTENAERE, Application of Distribution Coefficients to Radiological Assesment Models, Elsevier Applied Science Publishers, 1986.

21. J. E. TயL, H. R. MEYER, Radiological Assessment. A Textbook on Environmental Dose Analysis, NUREG/CR-3332, Washington, D.C., 1983.

22. Sediment $k_{d}$ and Concentration Factors for Radionuclides in Marine Environment, IAEA Technical Report Series, No. $247,1985$. 